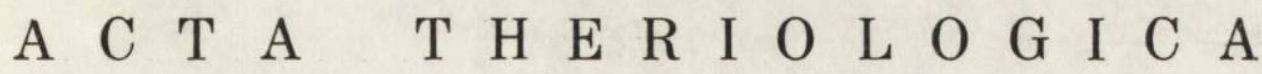 \\ VOL. $18,5:$ 107-118 \\ BIAŁOWIEŻA \\ April, 1973
}

Alina KOW A L SKA-D Y R C Z

\section{The Structure of Internal Genital Organs in Zapodidae (Rodentia)}

[With Plates I \& II]

\begin{abstract}
Investigations were carried out of histological structure of internal genital organs in four species of Zapodidae. The chief differences have been stated in the structure of gl. coagulantes, gl. bulbo-urethrales, colliculus seminalis, bulbus penis and farther part of the pars spongiosa urethrae in Sicistinae (Sicista) and in Zapodinae (Zapus, Napaeozapus). On the other hand, the structure of reproductive system in Zapodidae (especially in Sicista) is similar to that in Muroidea, this resemblance being particularly distinct in the structure and arrangement of the vesiculae seminales, gl. coagulantes, gl. prostaticae and even in gl. bulbo-urethrales. The similarities in the reproductive systems of Zapodidae, Dipodidae, Muroidea and Sciuridae have been discussed.
\end{abstract}

\section{INTRODUCTION}

Philogenetical relationships among rodents are not clear and disputable in many points. Therefore many authors are trying to improve the systematics of this group basing it on the structure of some internal organs. These should be the so-called conservative organs which are little dependent on the environmental selection. The reproductive system is undoubtly such a one. The attempts to base the systematics of rodents on the structure of the male genital organs have, among others, been undertaken by Vinogradov (1925), Mossman et al. (1932), A r a$t$ a (1964). The present paper discusses the structure of the male reproductive organs in some representatives of the family Zapodidae (superfamily Dipodoidea). 


\section{MATERIAL AND METHODS}

The material used for the investigations consisted of genital organs taken from: five sexually mature males of Sicista betulina (P a 1la s, 1778), two males of Zapus hudsonicus (Z i mmermann, 1780), two males of Zapus princeps J. A. A $11 \mathrm{en}$, 1893, and one male of Napaeozapus insignis (M ill e r, 1891).

All specimens of S. betulina were caught in Knyszyn Forest in May 1965. Genital organs being first prepared were fixed in Bouin or Zenker fluid. The whole urogenital complexes were put into paraffine and sectioned serially in the transverse and sagittal planes at $7-10 \mu$ thickness. They were stained with Delafield hematoxylin and eosin.

Genital organs of the remaining species were prepared from specimens fixed as a whole in alcohol, the quality of this material being therefore much lower for the histological purposes. Further procedure was analogical to that in case of S. betulina.

\section{DESCRIPTION OF GENITAL ORGANS}

The structure of the male reproductive system in $S$. betulina has been described in details, the analogical structures in Zapus and Napaeozapus being presented in comparison with the former one.

\section{Morphological Description}

The testes measure $7.2 \times 5.5 \mathrm{~mm}$ on the average. The seminiferous tubules are visible through the very thin tunica albuginea. The usually seen with an unaided eye large blood vessels branching all over the surface of the testes are absent. The epididymis has a characteristic structure. The head (the best developed part of the epididymis) has a form of a multilobular thick crescent and adheres the cranio-ventral surface of the testis. The head narrows gradually passing into a thin corpus adhering the medial surface of the testis. The tail of the epididymis is relatively feebly developed, it lies at the medial posterior surface of the testis (Fig. 1). The deferent ducts are in their terminal portions widened forming the ampullae measuring $1.6 \mathrm{~mm}$ each (Fig. 1, a). The vesiculae seminales lie dorsally to the bladder and form the most anterior portion of the tract. At their tips they are curved ventrally; they are slightly lumpy but rather regular in shape. The digitate tubues of the gl. coagulantes lie within the lesser curves of the vesiculae and extend up the lateral borders of the vesicles reaching cranially their recurved parts (Fig. 1, c).

Two pairs of the prostates are present. The ventro-lateral pair (Fig. 1$p v l)$ lies on both lateral and ventral surfaces of the prostatic urethra, extending from the basis of the seminal vesicles the glands reach as far as caudally to the bladder. The dorsal pair is thinner and lies on the dorsal surface of the prostatic urethra. The cephalic edges of the glands encroah upon the dorsal aspect of seminal vesicles. Both lobes of the 
dorsal prostate extend posteriorilly half-way up the membraneous urethra (Fig. 2, pd).

The bulbo-urethral glands, large and spherical, are lying cranially and laterally to the penile bulb. They measure $3.0 \times 2.2 \mathrm{~mm}$. Each gland is drained by single duct which is rather thick (Figs. 1 and 2, bu). The penis is relatively short, with characteristic structure of the glans penis (V i n og r a d ov, 1925; K u bi k, 1952).

In general outlines the morphological picture of the male reproductive system is in Zapus and Napaeozapus almost the same as in Birch mouse. The ampullae and the vesiculae seminales (Fig. 3) are only relatively and the coagulating and prostatic glands - much feebly developed. The chief difference is observed in the gl. bulbo-urethrales which are in both genera extremely small and plunged in the muscles of the bulbus penis.

\section{Micr Jscopic Structure}

2.1. The vas deferens and the associated glands. The tail of the epididymis is a uniform structure formed by the coils of the duct of the epididymis. It is not divided into the proximal part (defined by the ductus epididymis) and the distal one (defined by the vas deferens). The vas deferens while emerging from the tail of the epididymis has at first the structure resembling that of the epididymis duct. In its further portions the structure does not differ essentially from that encountered in Muridae. The ampulla vasis deferentis has a glandular structure. It is widest at its initial part and narrows gradually before entering the urethra. The interior of the ampulla is occupied by the pockets lined with a single-layered prismatic epithelium with spherical nuclei and granular cytoplasm. The secretion filling the pockets is homogeneous, highly eosinophilous. The central cavity to which the pockets are opening, is very small and irregular, hardly distinguished in the terminal portion of the ampulla.

The lumen of the vas deferens in its terminal portion within the colliculus seminalis is lined with epithelium which - thrown in folds - does not perform any glandular functions. The vasa deferentia are emptying on the colliculus seminalis separately from, and behind the openings of the seminal vesicle ducts. Free ampullar tubes do not occur in Birch mouse.

The vesiculae seminales. Microscopic structure of those glands is almost indentical with that in mice and Field vole. The only difference between them is the presence of a large central cavity continuing in Birch mouse from the apex of the vesiculae till their base: in muroid rodents the top of the gland is, as a rule, built of alveoles without central cavity.

Microscopic structure of the vas deferens and the associated glands in 
Zapus and Napaeozapus is similar to that in Sicista. The vesiculae seminales are, however, surrounded with a remarkably thicker layer of muscles.

2.2. The pars prostatica urethrae and its glands. The cranial portion of the urethra is surrounded with a ring of prostatic glands. The lumen of the urethra, being at first oval then pear and (within the colliculus seminalis) crecent-shaped, is lined with a transitional epithelium. Underneath the epithelium lies a layer of connective tissue containing many blood sinuses. Within this tissue (the mucosa), the ducts of the glands and the vasa deferentia are running (Fig. 4), namely: seminal vesicle ducts situated most dorsally $(v s)$, the deferent ducts $(v d)$ ventrally to them, and the coagulating gland ducts $(d c)$ medio-ventrally to the latter ones, one on each side. Along the dorsal, lateral and ventral walls of the urethra numerous prostatic gland ducts $(30-35$ on each side) are running $(d p)$. The whole is surrounded with a thick urethral muscle.

Some ventral ducts of the prostate, then some dorsal and lateral ones are opening most cranially. The seminal vesicles ducts are emptying to the lateral groovs of the urethra on the colliculus seminalis. They open independently and somewhat more cranially than the vasa deferentia (Fig. $5, v s)$. The openings of the vasa deferentia $(v d)$ are on the same level as those of the coagulating glands $(d c)$ - sometimes slightly cranially to them. Most caudally, outside the colliculus seminalis are emptying the remaining dorsal, ventral and lateral ducts of the prostate. The colliculus seminalis has a very simple structure being a broad fold of the dorsal wall of the urethra (Fig. 5). It has no blind pockets so much complicating this structure in the muroid rodents. Any traces of the utriculus prostaticus have been found within it either.

In Zapus and Napaeozapus the structure of the prostatic urethra is entirely different. This may be best observed within the region of colliculus seminalis (cf. Figs 6 and 5). One observes here the pockets of the urethra (a paired sinus genitalis) to which the coagulating glands, and next to them, the seminal vesicles are emptying (Fig. $6 \mathrm{sg}$, vs). Somewhat further caudally - some ducts of the dorsal and lateral prostatic glands are opening. The remaining ducts of the prostatic glands are opening to the main lumen of the urethra. The vasa deferentia $(v d)$ are emptying to the main lumen of the urethra, more caudally than the openings of the seminal vesicles. The ducts of the ventral prostate are opening most caudally, after the fusion of the pockets with the urethra. The utriculus prostaticus which occurs in form of a blindly terminated tubule with ramified lumen lies on the colliculus between the ducts of the seminal vesicles and the vasa deferentia (Fig. 6,ut). It opens to the urethra immediately its lumen is fused with the lumen of the pockets. 
The coagulating glands. They are built of broad tubes, the mucous membrane is arranged in curved folds which project into the lumen. Among the tubes one observes quite a lot of the connective tissue and the bands of smooth muscles. The epithelium of the tubes is prismatic, lower than that in the dorsal prostate, with very large spherical nuclei occupying the entire basal portion of the cell. The secretion filling the lumen of the tubes is homogeneous, staining pink with eosin. From each gland are emerging a few (most usually three) wide collecting tubes, on each side they join together forming one wide duct which enter the dorsal wall of the urethra.

In Zapus and Napaeozapus the structure of those glands is rather similar to that of the dorsal group of the gl. prostaticae. Each glands is, moreover, opening to the urethra by means of two ducts.

The glandulae prostaticae. Considering their microscopic structure they may ke divided into: (1) gl. prostaticae dorsales, (2) gl. prostaticae laterales, (3) gl. prostaticae ventrales. This division does not correspond thus to that based on morphological criteria.

The tubes of dorsal prostatic glands surround dorsally and laterally the bases of the vesiculae seminales and of the ampullae, and more caudally they are fused with the tubes of the lateral prostatic glands. The tubes are relatively narrow and separated from one another by the bands of smooth muscles and connective tissue (Fig. 7). They are built of prismatic epithelium, the cytoplasm is higly eosinophilous. The mucous membrane of the tubes has rare folds. The tubes are emptying with numerous ducts into the dorsal wall of the urethra.

The gl. prostaticae laterales and ventrales. The lateral tubes of the prostate begin cranially at the sides of the bladder and continue along the lateral surfaces of the prostatic urethra, caudally they pass gradually into the ventral group tubes. The group of lateral tubes, though closely related with the ventral group differs from the latter in structure. The average diameter of the tubes is larger than in the dorsal prostate, but smaller than in ventral group. The tubes are surrounded with the bands of smooth muscles and a good deal of connective tissue. The epithelium is prismatic, on the average, higher than in ventral group, and the secretion filling the lumen of the tubes is flocky and homogeneous.

The ventral tubes of the prostate are attached to the ventral surface of the urethra. They are wide, separated from one another by a small amount of connective tissue. The epithelium is low, prismatic with big oval nuclei, situated basally. The cytoplasm of the epithelial cells is distinctly more basophilous than in the remaining groups of the prostatic glands. The secretion filling the tubes is coarse-grained or has a form of 
droplets. Both groups are opening with numerous ducts into the lateral and ventral walls of the urethra.

In Zapus and Napaeozapus the tubes of the dorsal prostate being closely associated with the lateral tubes resemble them in structure too. The entire group of those dorso-lateral tubes opens to the urethra by 4-6 ducts on each side. The ventral tubes of the prostate are distinctly separated, their structure is similar to that in Birch mouse; usually they have two excretory ducts. The ducts in their terminal portion may be secondary branched (each duct is ramified into two or three branches).

2.3. The pars muscularis urethrae. The epithelium lining this part of the urethra is transitional and arranged into $2-3$ rows. The mucous membrane is thrown into longitudinal folds and contains large venous sinuses which are particularly numerous on the dorsal surface of the urethra. The presence of the gl. urethrales has been not stated.

The blood sinuses in the mucous membrane of the pars muscularis urethrae in Zapodinae are so well developed that the term corpus spongiosum is fully justified.

2.4. The gl. bulbo-urethrales and the pars spongiosa urethrae. The structure of the bulbo-urethral glands in Birch mouse is identical with that occuring in many muroid rodents (Fig. 8). One efferent duct which emerges frorn the median part of each gland is the continuation of its cavity. The ducts are very thick (Fig. 9, dbu). Their lumen is irregular and large lined with a single-layered prismatic epithelium. In the walls of the duct built of the connective tissue one observes glandular tubes emptying to its lumen. The tubes are built of prismatic epithelium with large spherical nuclei situated basally. The bands of connective tissue are penetrating among the tubes from the outer layer. The glandular tissue of the duct is more intensely staining with hematoxylin-eosin than the tissue of the very bulbo-urethral glands. The course of the ducts and their openings are described below.

The pars spongiosa urethrae. At its terminal part the pelvic urethra is considerably narrowing and forms a so called istmus urethrae (Fig. 9, ist). The istmus is a boundary between the pars pelvina and the pars spongiosa urethrae. There the urethra is curved ventrally and cranially keeping this course within the whole bulbus penis. Having left the bulbus the urethra arches posteriorily and in its distal part its arches also slightly dorsally. The proximal part of the spongy urethra that lies within the bulbus penis has a large lumen (Fig. 9, ps), a blind, dorsal diverticulum known as the sinus urethrae bulbi does not occur here, the corpus spongiosum is, however, highly developed. The epithelium lining this part of the urethra is thrown into numerous folds; in the lateral walls of the urethra, next to istmus one observes tiny agglomerations of gland. 
Both course and the openings of the bulbo-urethral glands are of a great interest being rarely observed. After having left the gland the ducts pass through the $m$. urethralis of the terminal part of the pelvic urethra and penetrate into the bulbus penis. There, they course within the corpus spongiosum parallelly to the posterior (dorsal) wall of the urethra (Fig. 9, $d b u$ ) turning with it ventrally, further they penetrate into the epithelium of the urethra at the site where the urethra having left the bulbus arches posteriorily, and finally they open to its lumen. At this terminal portion the diameter of the ducts decreases rapidly and their walls lose their glandular character. Thus in Birch mouse the openings of the gl. bulbo-urethrales are situated distally to the bulbus penis being found in the medial portion of the pars spongiosa urethrae. The lumen of the latter is lined with the epithelium resembling this occuring in the urethra within the bulbus penis.

In Zapodinae this part of the genital reproductive tract differs significantly. Within the bulbus penis one states the presence of the sinus urethrae bulbi which is surrounded with a well developed corpus spongiosum (Fig. 10, su). The particularly small bulbo-urethral glands (Fig. 11) are plunged in the muscles of the bulbus penis. A very thick glandular efferent duct, whose diameter almost equals that of the gland, emerges from the distal end of each gland. The duct turns toward the sinus running paralelly to the body of the gland, it enters the spongy tissue of the bulb and opens into the sinus urethrae bulbi (Fig. 10, dbu). The gland itself is built of the tissue almost identical with that of the efferent duct; it consists, namely, of the tubes differing as to diameter, built of pretty high epithelium; the cytoplasm showing a strong affinity to eosin. Irregular cavity of the gland is continuous with the lumen of the duct. Singular bands of the striated muscles are present in outer sheath of the gland and in the wall of the duct.

Regular folds of the mucous membrane (septae) are present in the pars spongiosa urethrae, caudally to the sinus urehrae; they have never been observed in Sicista betulina (Fig. 12).

\section{DISCUSSION}

The comparison made between the male reproductive systems in Sicista betulina (Sicistinae) and Zapus and Napaeozapus (Zapodinae) has shown a number of significant differences in the structure of separate organs, namely: (1) the coagulating glands, (2) the colliculus seminalis, (3) the bulbo-urethral glands, (4) the pars spongiosa urethrae, and (5) in the site at which the ducts of the bulbo-urethral glands are opening to the urethra. Considering, moreover, the descriptions presented by $\mathrm{Grosz}$ 
(1905) the structure of genital tract in Dipus aegypticus (Dipodidae) has much more in common with Zapus and Napaeozapus than with Sicista. From the Figures 15, 16a, 16b presented by this author (G ros z, l.c.) it, follows that the reproductive system is in Dipus almost identical morphologically with that in Zapus, except for the bulbo-urethral glands which are large and situated on the dorsal surface of the bulbus in Zapodinae being extremely small and hidden in the muscles of the bulbus. It seems also that the microscopic structure of the ampullae in Dipus is most similar to that in Napaeozapus; the seminal vesicles in Dipus and Zapus are identical, they possess, among others, a strong muscular coat; on the colliculus one observes the sinus genitalis to which the dorsal and some lateral tubes of the prostate are emptying; within the bulbus penis appears a large sinus urethrae to which the ducts of slightly "curved " gl. bulbourethrales are opening. The ducts of the bulbo-urethral glands have a glandular character and - according to G r os z (l.c.) - form »accessorylike" gl. Cowperi. O u d e m a n s (1892) quotes also that according to $\mathrm{T}$ u rn e r the Cowperi glands in Dipus aegyptius are "curved upon themselves". All the mentioned above characters have been also stated in Zapodinae Hence, assuming the structure of internal male organs as the criterion in establishing a relationship between the taxons - genera Zapus and Dipus are more closely related than Zapus and Sicista. Vinogradov (1925) has stated significant differences in the structure of glans penis and os penis between Dipodidae and Zapodidae but the diagnosis given by him for those families does not seem to be sure nor univocal (as he underlined too). The characters of the external genital organs are certainly of a taxonomical importance in determining the interspecific or intergeneric relations, but do not seem to be sufficient criteria for higher taxons because of their great variability. The suggestions formulated by $\mathrm{M} \mathrm{os-}$ $\mathrm{s} \mathrm{m}$ a n (1953) should be also taken into consideration. According to this author in establishing true relations between the taxons of a higher rank the most useful are the characters of the organs whose evolutionary development occurred rather independently of the environmental selection. The internal genital organs may be undoubtly considered as such ones. It is evident, however, that even then we shall not obtain any universal criteria to define univocally taxons of different rank.

Mossman (1932) states, that a particular structure of the bulbo-urethral glands in Sciuridae (a thick efferent duct curved spirally around the gland) and some modifications of distal parts of their efferent ducts (bulbar gland, penile duct) are difficult to interpretation since the comparative data for other mammals are still not available. In view of this fact it should be noticed that some relations may be found between the reproductive system in Dipodoidea and that in Sciuridae. In Zapus 
and Napaeozapus the bulbo-urethral glands are exceptionally small and distinctly curved; and in Dipus however, they are relatively large but also "curved upon themselves " like in Sciuridae (T u r n e r, quoted after $\mathrm{O}$ u d e m a n s, 1892). All glands have very thick glandular efferent ducts emptying to the sinus urethrae bulbi. Because of those characters they may be compared with Tamiasciurus whose classification among the Sciuridae is questioned by $\mathrm{M}$ os s m a n (l.c.). In Tamiasciurus very small gl. bulbo-urethrales are opening to the sinus urethrae. In true Sciuridae, however, sinus urethrae is absent and the ducts of those glands modified into bulbar gland and penile duct are emptying at the terminal portion of the pars spongiosa urethrae. In Sicista though the bulbo-urethral glands resemble in structure that in the Muroidea, but its efferent ducts are opening to the urethra in a way suggesting its relationship with Sciuridae. The sinus urethrae bulbi is absent; very thick, glandular ducts of the bulbo-urethral glands penetrate into the bulbus penis running parallelly to the dorsal (posterior) wall of the urethra and open to the pars spongiosa urethrae distally to the bulbus penis. This is rather rare a phenomenon since, as a rule, the ducts of bulbo-urethral glands are opening to the urethra, within the bulbus, on the boundary between the pars muscularis and the pars spongiosa urethrae, most usually they open to the sinus urethrae, if it is present ( $\mathrm{H} \mathrm{a} \mathrm{l1}, 1936)$. In Sicista this situation is intermediary between that known in most mammals and Sciuridae. It might be supposed that the $g l$. bulbi and the ductus penis, characteristic of the Sciuridae, had been developed by the atrophy of the septum between the ducts mutually adhering and by the caudal translocation of their openings.

Besides the possible relationship with the Sciuridae the male reproductive system in Zapodidae displays many characters common with muroid rodents. The general morphology of the gl. accessoriae as well as some details of their microscopic structure (the structure of the coagulating glands, seminal vesicles and bulbo-urethral glands) are strikingly resembling in Sicista betulina and Apodemus agrarius (Kow a ls k aDyrcz \& Paw $ł$ ow ska-Indyk, 1969). Thus considering the structure of the male reproductive system the position of Dipodoidea in the suborder Myomorpha, together with Muroidea seems to by fully justified.

Acknowledgement:. The whole material used for investigations has been obtained from the Mammals Research Institute of the Polish Academy of Sciences at Białowieża. It came partially from the captures (Birch mouse), and partially from the collections of the Institute received by the exchange (Zapus, Napaeozapus). The authoress is greatly indepted to Professor Z. Pucek for his kindness in making the material available to her. 


\section{REFERENCES}

1. Arata A. A., 1964: The anatomy and taxonomic significance of the male accessory reproductive glands of muroid rodents. Bull. Florida State Mus., 9: 1-42.

2. Grosz S., 1905: Beiträge zur Anatomie der accessorischen Geschlechtsdrüsen der Insectivoren und Nager. Arch. mikr. Anat. Entwicklungsgesch., 66: 567-608.

3. H a $11 \mathrm{~K}$., 1936: The structure and development of the urethral sinus in the male white mouse with notes on its occurence in other Rodents. J. Anat., 70: 411-428.

4. Kowa lska-Dyrcz A. \& Paw 10 w ska-Indyk A., 1969: The male accessory reproductive organs in the striped field mouse. Acta theriol., 14, 32: 433-478.

5. K u bik J., 1952: Badania nad morfologią i biologią smużki (Sicista betulina Pa 1la s) z Białowieskiego Parku Narodowego. Annls Univ. M. Curie-Skłodowska, C $7,1: 1-63$.

6. Mossman H. W., Lawlah J. W. \& Bradley J. A., 1932: The male reproductive tract of the Sciuridae. Amer. J. Anat., 51: 89-141.

7. M o s s m a n H. W., 1953: The genital system and the fetal membranes as criteria for mammalian phylogeny and taxonomy. J. Mamm., 34: 289-298.

8. O u dem ans J. Th., 1892: Die accessorischen Geschlechtsdrüsen der Saügetiere. Haarlem.

9. Vinogradov B. S., 1925: On the structure of the external genitalia in Dipodidae and Zapodidae (Rodentia) as a classificatory character. Proc. zool. Soc. Lond., 2: $577-585$.

Received, December 20, 1972

Departament of Comparative Anatomy,

Wrocław University,

Sienkiewicza 21, 50-335 Wrocław, Poland.

\section{Alina KOWALSKA-DYRCZ}

\section{BUDOWA MĘSKICH WEWNĘTRZNYCH NARZĄDÓW PECIOWYCH \\ U ZAPODIDAE (RODENTIA)}

\section{Streszczenie}

Przeprowadzono badania histologiczne budowy męskich wewnętrznych narządów płciowych Sicista betulina (P a 11 a s) - (Sicistinae) oraz Zapus princeps J. A. All e n, Zapus hudsonicus (Zimmermann) i Napaeozapus insignis (Miller) - (Zapodinae). Stwierdzono istnienie dość zasadniczych różnic $\mathrm{w}$ budowie tych narządów u przedstawicieli obu podrodzin; dotyczą one: struktury gl. coagulantes, budowy colliculus seminalis (porównaj Fig. 5 i 6), budowy gl. bulbo-urethrales (Fig. 8 i 11) i miejsca ujścia ich przewodów do uretry (Fig. 9 i 10), budowy wewnętrznej bulbus penis i dalszej partii pars spongiosa urethrae (Fig. 12). Sądząc z opisu Grosza (1905), wydaje się, że Dipus aegyptius (Dipodidae) posiada układ płciowy bardziej zbliżony do Zapodinae niż smużka.

Stwierdzono ponadto duże podobieństwo między wewnętrznymi układami płciowymi Zapodidae (szczególnie Sicista) i Muroidea. Podobieństwa te dotyczą występowania, rozmieszczenia i budowy takich gruczołów jak: vesiculae seminales, gl. coagulantes, prostata - a nawet gl. bulbo-urethrales (Sicista). 
Istnieją również pewne cechy w układzie płciowym Dipodoidea, które nawiązują, jak się wydaje, do Sciuridae. Do tego typu cech zaliczyć należy występowanie „zakrzywionych" gl. bulbo-urethrales (Zapus, Napaeozapus) oraz fakt, że u Sicista przewody tych gruczolów uchodzą do pars spongiosa urethrae, dystalnie od bulbus penis, a więc o wiele bardziej kaudalnie niż to ma miejsce $u$ przebadanych dotąd gatunków ssaków. 
Plate I

Fig. 1. The urogenital system in Sicista betulina, ventral side, $\sigma^{*}$ ad. Magn. $3 \times$.

Fig. 2. The urogenital system in Sicista betulina, dorsal side, $\sigma^{x}$, ad. Magn. $3 \times$.

Fig. 3. The urogenital system in Napaeozapus insignis, ventral side, $\sigma^{*}$ ad. Magn. about $3 \times$.

Fig. 4. Cross-sections through the urethra in S. betulina on a level with the crista urethralis.

Fig. 5. Cross-section through the urethra in $S$. betulina made on a level with the colliculus seminalis.

Fig. 6. Cross-section through the urethra in $Z$. hudsonicus made on a level with the colliculus seminalis.

\section{Plate II}

Fig. 7. A fragment of the tissue of the dorsal prostata in S. betulina.

Fig. 8. A fragment of the tissue of bulbo-urethral gland in S. betulina.

Fig. 9. A fragment of a longitudinal section through the bulbus penis in S. betulina.

Fig. 10. A fragment of a longitudinal section through the bulbus penis in Z. hudsonicus.

Fig. 11. Longitudinal section through the gl. bulbo-urethralis in Z. hudsonicus. Fig. 12. A fragment of the longitudinal section through the pars spongiosa urethrae, made distally to the bulbus penis in $\mathrm{Z}$. princeps.

\section{KEY TO ABBREVIATIONS}

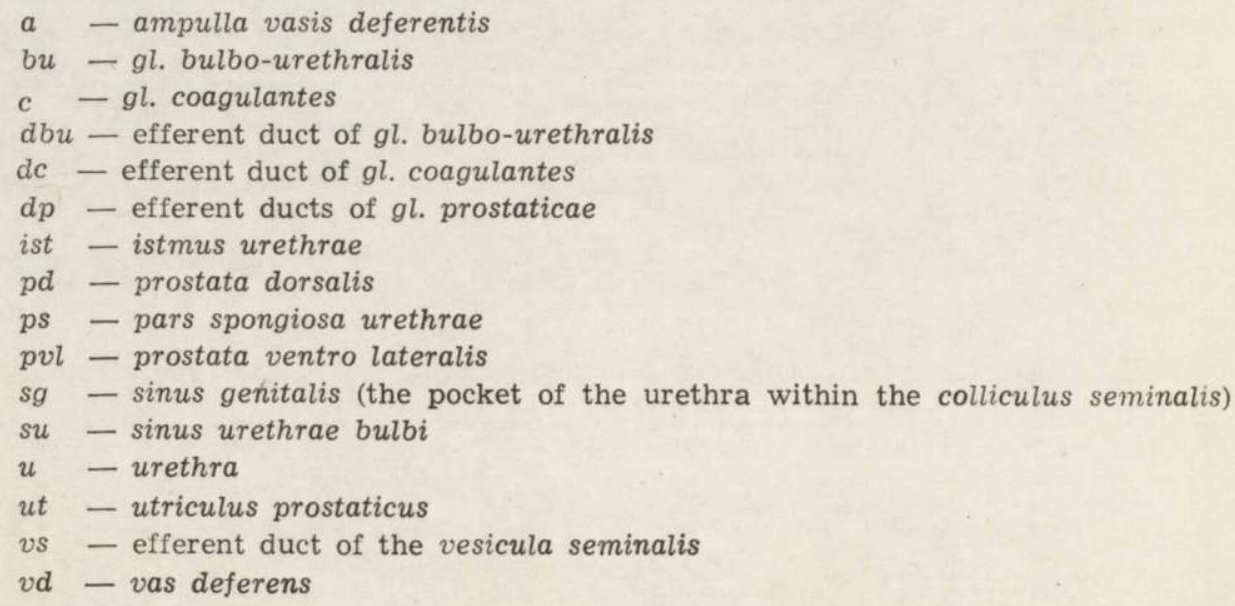



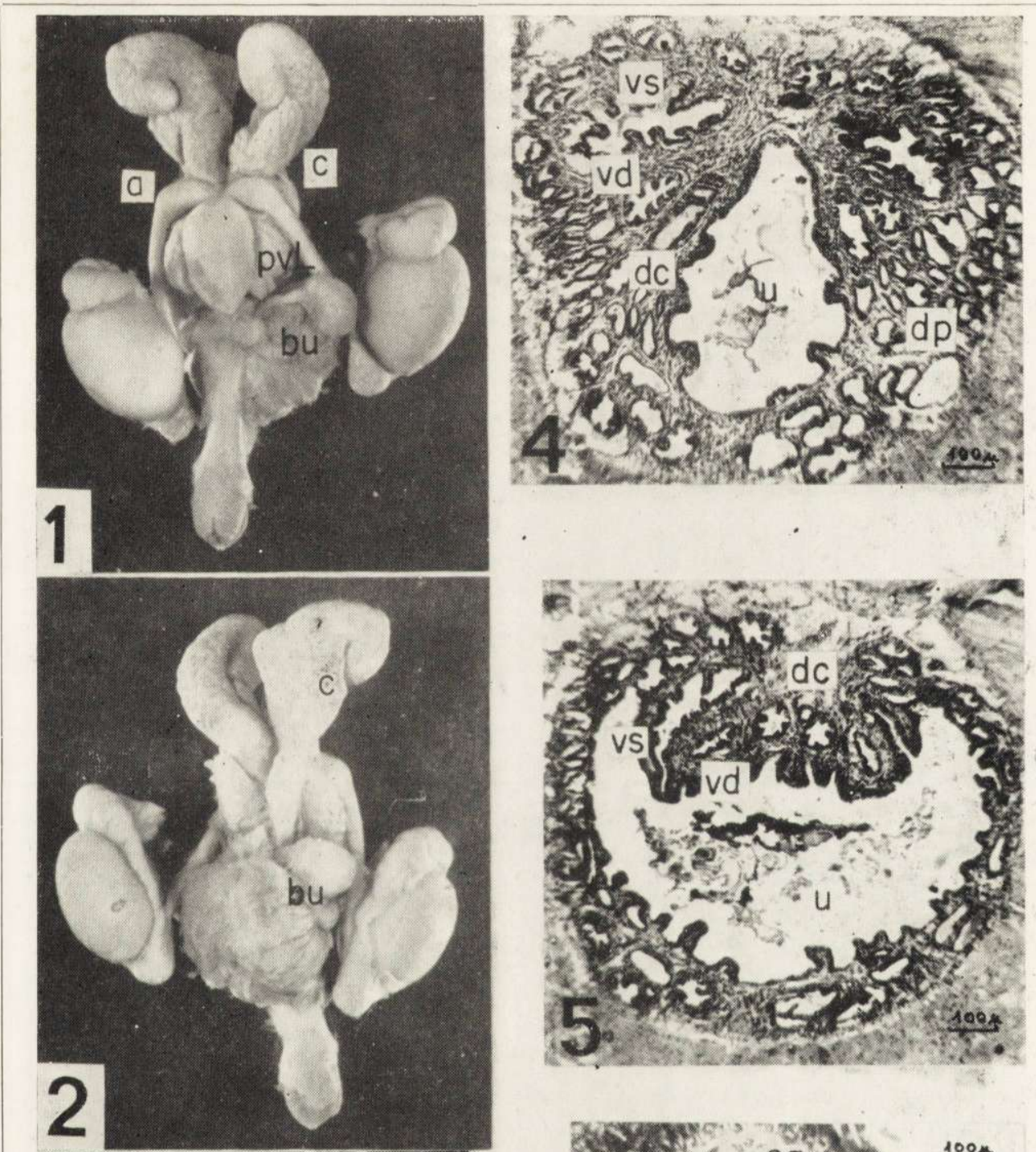

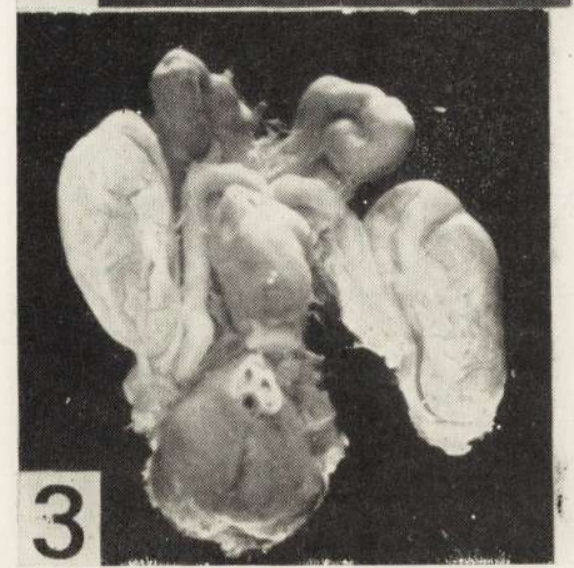

A. Kowalska-Dyrcz
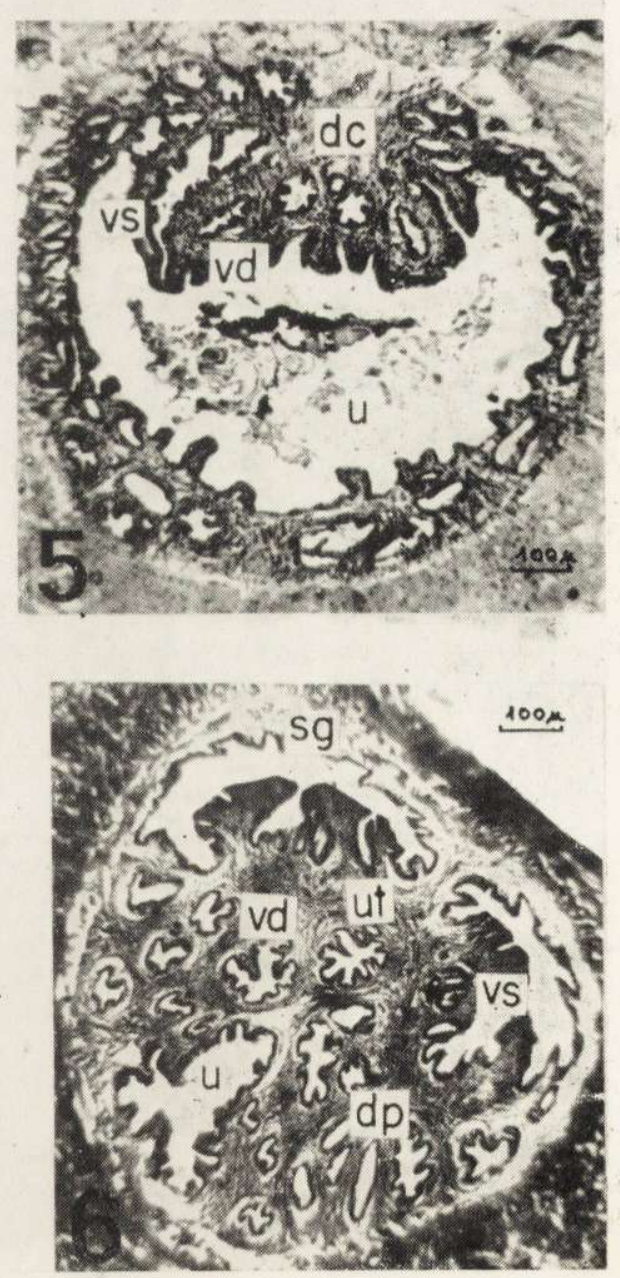

B. Kokurewicz phot 


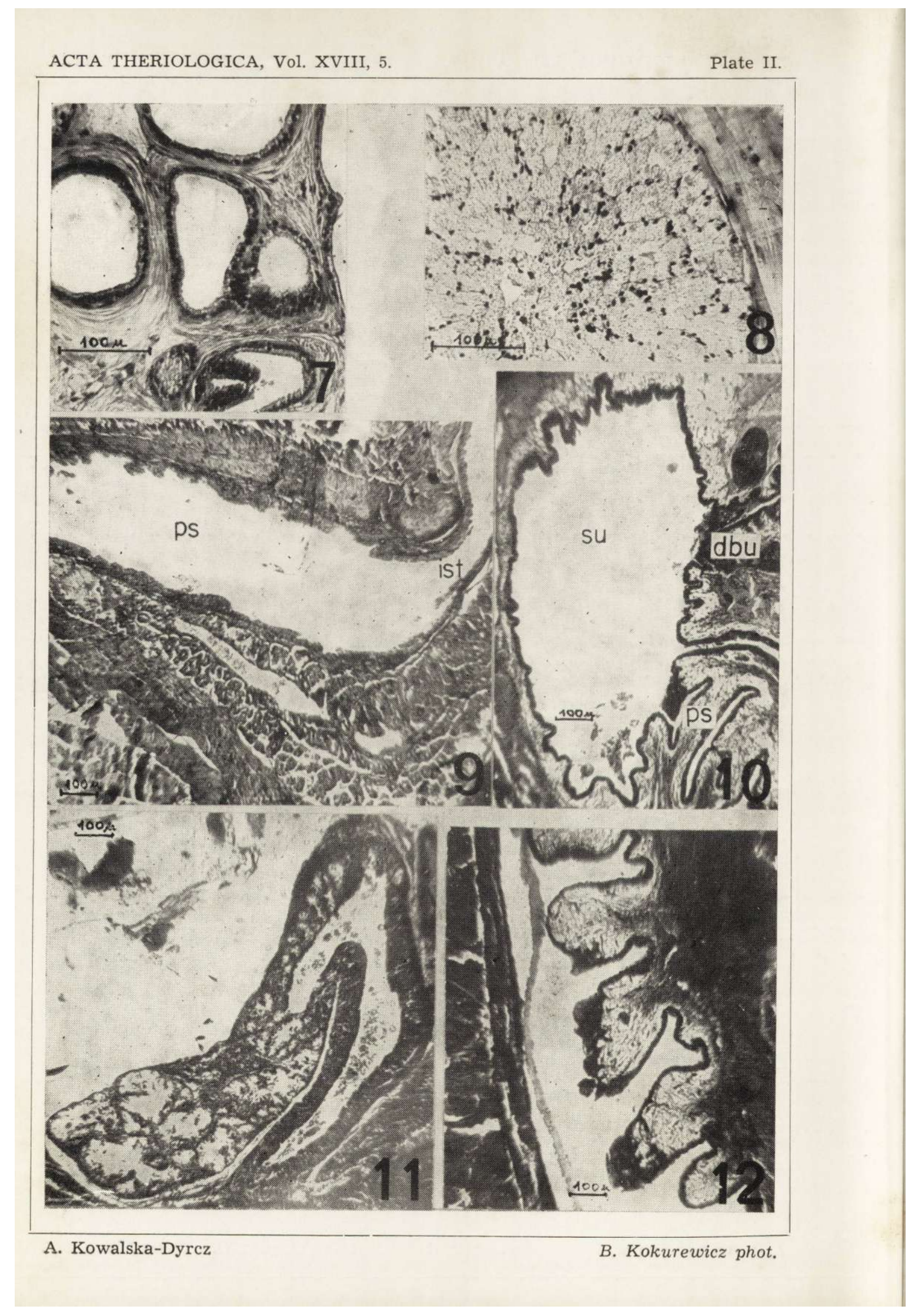

